\title{
Survivors of neuroblastoma and ganglioneuroma and their families
}

\author{
SARAH BUNDEY AND KATHLEEN EVANS
}

From the Department of Clinical Genetics, Birmingham Maternity Hospital, Birmingham B15 2TG; and MRC Clinical Genetics Unit, Institute of Child Health, 30 Guilford Street, London WC1N 1EH

SUMMARY The main purpose of this study was to see if the offspring of surviving neuroblastoma, ganglioneuroblastoma, or ganglioneuroma patients have themselves a risk for developing tumours. No such risk was found. There was a total of 45 liveborn children who were all healthy. These children have passed through about 37 lifetimes of risk for developing neuroblastoma and about six lifetimes of risk for developing ganglioneuroma. No excess of cancers was found among parents and sibs.

It was interesting that there was a large female excess $(35: 12)$ among these survivors. One factor which may give rise to a better prognosis in females is the tendency of their tumours to mature to benign forms.

Neuroblastoma is a childhood tumour with a poor survival rate. Familial cases have been reported but these are rare. In 1972, Knudson and Strong ${ }^{1}$ suggested that neuroblastoma was produced by two mutations, the first of which could be carried by a dominant gene. This suggestion was analogous to their hypothesis for the aetiology of retinoblastoma. The argument was based on observations that the rare familial cases of neuroblastoma have an earlier onset than the non-familial cases, with $56 \%$ being diagnosed during infancy compared to $26 \%$ of unselected, largely non-familial cases. Also, multiple tumours occur in only $5 \%$ of unselected cases, but in nearly one-quarter of familial cases.

Since there has been an increase in the incidence of retinoblastoma ${ }^{2}$ following improved survival of patients, it was felt to be important to recognise whether the same could happen with neuroblastoma. The main aim of this study, therefore, was to observe whether the children of neuroblastoma patients who survived to adult life ran an increased risk of developing tumours.

Patients with a ganglioneuroblastoma or a ganglioneuroma were also included in the study. There were two main reasons for this.

Firstly, it is established that neuroblastomas may mature histologically via a ganglioneuroblastoma into a ganglioneuroma, at the same time improving their clinical prognosis. ${ }^{3}$ Secondly, reports of familial neuroblastoma include two certain examples and two possible examples of a parent with a ganglioneuroma having one or more children with a neuroblastoma (table 1).

In order to estimate the risk periods for developing $\stackrel{\mathbb{Q}}{\triangle}$ neuroblastoma we have constructed a cumulative $\overrightarrow{\vec{O}}$ age of onset table (table 2) using data from two 3

TABLE 1 Reported instances of neuroblastoma (NB), ganglioneuroblastoma $(G B)$, or ganglioneuroma $(G N)$ in close relatives (excluding identical twins)

\begin{tabular}{|c|c|}
\hline Reference & Relatives affected \\
\hline $\begin{array}{l}\text { Dodge and Benner } 4 \\
\text { Zimmermann } 5 \\
\text { Chatten and Voorhess } 6 \\
\text { Gerson } \text { et }^{6} \text { al }^{7} \\
\text { Griffin and Bolande } 8\end{array}$ & $\begin{array}{l}2 \text { sibs with NB } \\
\text { Father with GN; } 2 \text { children with GB } \\
\text { Mother with GN } \\
4 \text { children with NB } \\
1 \text { sib with NB } \\
1 \text { sib with NB maturing to GN }\end{array}$ \\
\hline $\begin{array}{l}\text { Feingold } \text { et } a l^{9} \\
\text { Wong et al }{ }^{10} \\
\text { Hardy and Nesbit } 11\end{array}$ & $\begin{array}{l}2 \text { sibs with NB } \\
2 \text { sibs with NB* } \\
1 \text { sib with NB, } 1 \text { sib with } \mathrm{GB}^{*} \\
1 \text { paternal cousin with NB } \\
2 \text { paternal cousins with Wilms' tumours }\end{array}$ \\
\hline Waggett et al 12 & $\begin{array}{l}\text { (1) } 2 \text { sibs with NB } \\
\text { (2) } 2 \text { sibs with NB }\end{array}$ \\
\hline $\left.\begin{array}{l}\text { Klein and Plöchl13 } \\
\text { Plöchl14 }\end{array}\right\}$ & $\begin{array}{l}1 \mathrm{sib} \text { with } \mathrm{NB} \\
1 \mathrm{sib} \text { with } \mathrm{GB} \\
1 \text { 2nd cousin once removed with NB }\end{array}$ \\
\hline $\begin{array}{l}\text { Bergstrom and Long }{ }^{15} \\
\text { Pegelow } \text { et al } 16\end{array}$ & $\begin{array}{l}\text { Father and son with GN } \\
\text { Index patient, a maternal half-sib, } \\
\text { and a paternal half-sib with NB }\end{array}$ \\
\hline Arenson et al 17 & Father and son with NB \\
\hline
\end{tabular}

*Father had high levels of urinary catecholamines but no demonstrable $\overparen{\mathbb{D}}$ tumour. 
TABLE 2 The proportion of patients from unselected series of patients with neuroblastoma, ${ }^{18}$ ganglioneuroblastoma, ${ }^{19}$ and ganglioneuroma ${ }^{19}$ who had developed signs of disease by specific ages

\begin{tabular}{llll}
\hline $\begin{array}{l}\text { Age by } \\
\text { which } \\
\text { tumour had } \\
\text { appeared }(y r)\end{array}$ & $\begin{array}{l}\text { Neuroblastoma } \\
\text { (504 cases) }\end{array}$ & $\begin{array}{l}\text { Ganglio- } \\
\text { neuroblastoma } \\
(17 \text { cases })\end{array}$ & $\begin{array}{l}\text { Ganglioneuroma } \\
\text { (109 cases) }\end{array}$ \\
\hline 1 & 0.26 & 0.23 & \\
2 & 0.43 & 0.23 & - \\
3 & 0.58 & 0.23 & - \\
4 & 0.72 & 0.58 & 0.02 \\
5 & 0.81 & 0.65 & 0.02 \\
6 & 0.89 & 0.65 & 0.02 \\
10 & 0.96 & 0.65 & 0.06 \\
15 & 1.00 & 0.65 & 0.10 \\
20 & & 0.70 & 0.18 \\
30 & & 0.88 & 0.50 \\
\hline
\end{tabular}

unselected series. ${ }^{18} 19$ Although we use these data, we are aware that neuroblastoma may occur in adult life; this, however, is clearly very rare. ${ }^{20}$

\section{Methods}

Ascertainment of patients with the diagnosis of neuroblastoma, ganglioneuroblastoma, or ganglioneuroma took place in 1973. The following hospitals allowed their records to be searched: The Hospital for Sick Children, London; St Bartholomew's Hospital, London; Brompton Hospital, London; The London Chest Hospital; Walsgrave Hospital, Coventry (Thoracic Unit); and the Queen Elizabeth Hospital, Birmingham. In addition, names were obtained from the Oxford Survey of Childhood Cancers and from the Birmingham and West Midlands Regional Cancer Registry.

In this way we obtained the names of 50 patients who were known to be alive, who were born in 1956 or earlier, and who lived in England (excluding the Manchester and Newcastle regions which were conducting their own surveys). All these patients had histological confirmation that their tumour was either a neuroblastoma, or a ganglioneuroblastoma, or a ganglioneuroma.

Of these 50 patients whose names were obtained, 42 (or their parents) agreed to be visited at home. Two could not be traced, one had subsequently moved to Ireland, three patients refused to cooperate, and in two instances the general practitioner advised against a home visit. Of the eight patients not visited, information about children was obtained from the general practitioner for five patients. Information about parents was unavailable for two further patients who were adopted.

This left in the study 47 patients: 17 who had had a neuroblastoma, four who had had a ganglioneuroblastoma, and 26 who had had a ganglioneuroma. The patients (or in eight instances their parents, because the patient was unavailable through work or through living abroad) were visited at home in 1973 and 1974. Information was obtained about the patient's health (including any manifestation of neurofibromatosis) and about his/her family. Specific questions were asked about tumours or congenital malformations in children, sibs, parents, and grandparents of the index patient. This initial study showed that few children had yet been born to patients, but that several patients were likely to get married during the next few years. Therefore in 1979 and 1980 we attempted to obtain further information about the children of patients by writing to them or to their general practitioners, or to both. In this second survey new information about the health of relatives was not obtained. We were able to followup all but two of the original patients; one patient had moved away and could not be traced and another refused to co-operate further. No patient died between ascertainment and completion of the study in 1980.

As some of the patients may be included in other follow-up studies, their hospital numbers are listed in the appendix.

In estimating the risk period for developing neuroblastoma passed by a child reaching a certain age in good health, we have used the data from table 2. For example, if a child in the series was healthy at the age of 2 , we have assumed that he or she has passed 0.43 of a lifetime of risk for developing neuroblastoma.

\section{Results}

\section{NEUROBLASTOMA SURVIVORS}

The 17 neuroblastoma patients consisted of six males and 11 females with an age range in 1980 of 24 to 36 years. The ages at which their neuroblastomas were recognised are listed in the appendix and displayed in the figure. Two patients were paraplegic and incontinent and were unlikely to marry; one was ill with metastases; one had a mild disability in her legs resulting from spinal extension of her tumour; and 13 patients were leading entirely normal lives. Eight of the 17 patients had received pelvic irradiation as a child and only one of these has had children; three patients are known to be sterile. Nine of the 17 patients had married and four of them had had seven living children, aged 16 months to 8 years; details are shown in the appendix. No child had a neuroblastoma. One baby was a macerated stillbirth, attributed to strangulation by the umbilical cord. 


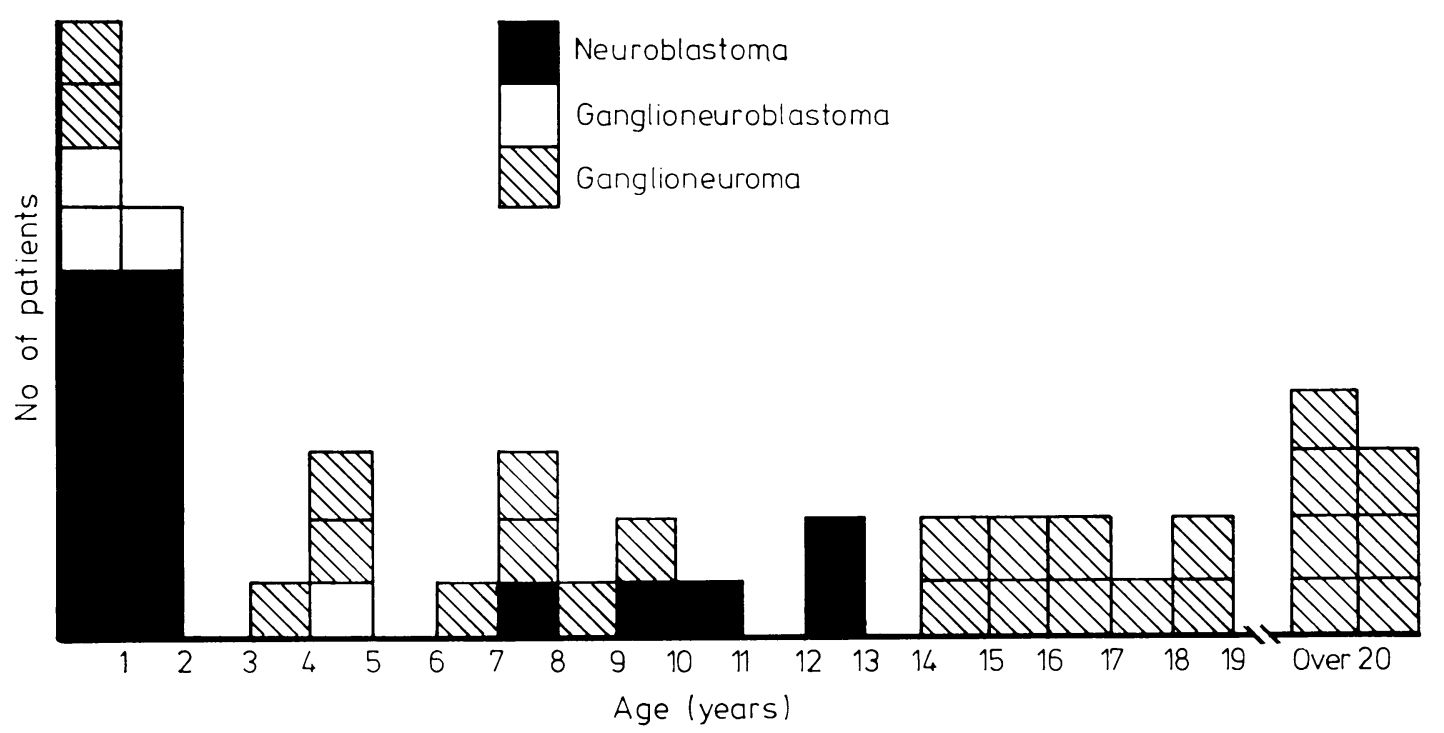

FIGURE Age of onset in 47 index patients

Using the data in table 2 we have estimated that these seven living children have passed about 4.6 lifetimes of risk for developing neuroblastoma.

There were 25 liveborn sibs and all were healthy. Information was available on 30 of the 34 parents: one mother had a carcinoma of the breast at the age of 61 , one father died of hypernephroma at 49 , and one father died of carcinomatosis from an unknown primary at the age of 37 . The mean age of 27 living parents was 52 years.

Information about parental age at the birth of the index patient was available for 16 mothers and 16 fathers. The mean maternal age was 28.9 years (SE 1.16 years) and the mean paternal age was 31.2 years (SE 1.44 years). No birth order effect was present so we made a comparison with the mean population maternal ages for the individual years in which the patients were born (Registrar General's figures for England and Wales). The combined mean of these yearly maternal ages was $28 \cdot 0$ years, not significantly different from our observed mean maternal age. The expected paternal ages were individually estimated from the above maternal age figures for the population, plus the average fathermother age difference. ${ }^{21}$ The mean of these expected paternal ages came to $29 \cdot 66$ years. Although the observed mean paternal age was higher than this, the difference was not significant.

SURVIVORS WITH GANGLIONEUROBLASTOMA These four patients were all female, aged between 25 and 30 years in 1980. Three are leading entirely normal lives and one has mild symptoms only. One received pelvic irradiation as a child. All patients are married and two have had a total of three healthy children, aged 9 months, 6 years, and 4 years. Together, they have passed about 1.8 lifetimes of risk for developing neuroblastoma. No tumours were found in first degree relatives. The mean parental age at the births of the patients was 23.7 years for three mothers and $27 \cdot 3$ years for three fathers.

SURVIVORS WITH GANGLIONEUROMA

There were 20 females and six males; 25 patients were entirely healthy and one had a spastic paraplegia from extensive pelvic and spinal involvement. Their present ages ranged from 26 to 78 years and the ages at which their tumours developed are listed in the appendix and displayed in the figure. Twenty-one patients had married and had between them 35 liveborn children, all now healthy, aged between 1 and 51 years. We have estimated, using table 2 , that these 35 living children have passed $30 \cdot 5$ lifetimes of risk for developing neuroblastoma, and nearly six lifetimes of risk for developing ganglioneuroma. One daughter had congenital pyloric stenosis and one of two stillbirths was malformed with spina bifida and hydrocephalus. None of 67 liveborn sibs had a childhood tumour.

Information was available on the health of 44 parents; one mother had carcinoma of the breast at the age of 63 , one father had a seminoma of a testis 
removed at the age of 40 , and another father had a plasmacytoma of a metatarsal at the age of 66 . The mean age of 41 living parents was 60.0 years.

The mean parental age at the birth of the index patients was $28 \cdot 5$ years (SE $1 \cdot 82$ years) for 23 mothers and 31.7 years (SE 0.68 years) for 21 fathers. The expected mean parental ages were obtained from population figures as described earlier. The expected mean maternal age was $\mathbf{2 8} \cdot \mathbf{8}$ years (not different from that observed). The expected mean paternal age was 30.6 years. As with the neuroblastoma patients, the observed mean paternal age is higher than this, but not significantly increased.

Overall, the 47 patients studied consisted of 12 males and 35 females who were aged 25 to 78 years in 1980. They had a total of 45 liveborn children who were ail healthy. These children have passed through about 37 lifetimes of risk for developing neuroblastoma and about six lifetimes of risk for developing ganglioneuroma.

\section{Discussion}

Other studies have also shown a female excess among survivors with neuroblastoma, although initially more males are affected than females. ${ }^{18} 22$ For example, Wilson and Draper ${ }^{22}$ found a male:female ratio of $268: 219(1 \cdot 22)$ among their patients at onset, but among the $23 \%$ who survived for 3 years or longer, the sex ratio was reversed: $48: 66(0 \cdot 73)$. The present study also demonstrates a marked female excess in patients who have survived to adult life: $6: 11(0.54)$ for neuroblastoma survivors only and $12: 35(0 \cdot 34)$ if all patients are included. This is obviously of importance in understanding natural resistance to neuroblastoma. Since evidence for maturation of a neuroblastoma to a ganglioneuroma (from two biopsies taken at different times) has been found more often in females, Wilson and Draper ${ }^{22}$ have suggested that the main reason for improved survival in females could be the greater tendency of their tumours to mature into a benign form. The excess of females among patients with benign ganglioneuroma would support this view.

The proportion of neuroblastoma patients who have had children is small. The reason for this is not entirely clear, but some of the infertility may be the result of pelvic irradiation.

The present study does not reveal a risk that the offspring of neuroblastoma patients may themselves develop tumours. However, the numbers are small. To them may be added figures from a previous study by $\mathrm{Li}$ and $\mathrm{Jaffe},{ }^{23}$ in which there were seven adult females who had survived a neuroblastoma and three who had survived a ganglioneuroblastoma. These women had between them 18 liveborn children who had no evidence of neuroblastoma (although two premature babies died soon after birth).

Knudson and Strong ${ }^{1}$ have proposed that $22 \%$ of neuroblastoma patients carry a dominant germinal mutation, and they suggest a Poisson distribution for somatic mutations. Thus, of the gene carrying neuroblastoma patients, about one-quarter would be bilaterally affected and about three-quarters unilaterally affected. About one-third of gene carriers would not receive a second hit (a somatic mutation) and therefore would not develop neuroblastoma. Using these figures, we can calculate the expected incidence of disease among the offspring of unilaterally affected patients, which would be appropriate for the patients in the present series. (From the practical point of view we might expect almost all bilaterally affected patients to die, and indeed there was none in the present series.) About one in six of unilaterally affected patients might possess a dominant germinal mutation, with a 1 in 12 risk for their offspring receiving the predisposing dominant gene. However, only about two-thirds of gene carriers are likely to develop neuroblastoma and so the overall theoretical risk for offspring would be about 1 in 18 .

Our negative study, together with that of $\mathrm{Li}$ and Jaffe, ${ }^{23}$ has not yet dismissed the possibility of a 1 in 18 risk. However, it seems unlikely that there is a high risk for the offspring of neuroblastoma patients who survived treatment in the 1950s.

The present study is more encouraging regarding the offspring of patients with ganglioneuroma. Although some patients with this tumour have been reported to have had one or more children with neuroblastoma (table 1), there was none in the present series. We have estimated that the offspring of the ganglioneuroma patients have passed about 30 lifetimes of risk for developing neuroblastoma.

There was no obvious excess of cancers among the first degree relatives of patients in this series, although the observation that two of the fathers had relatively unusual tumours (Wilms' tumour and seminoma of the testis) may be of interest. There was also no excess of congenital malformations in the sibs or children of the patients.

We are grateful to those many consultant surgeons and radiotherapists who allowed us to include their patients. We also thank Drs J E Freeman, R AbbeySmith, Alice Stewart, G J Draper, J A H Waterhouse, and medical records officers and statisticians who helped us in obtaining names of patients. We thank Mrs Joan Warren for visits to some of the patients and those general practitioners who supplied further 
information. We are grateful to Professor C O Carter for his help during the study and in preparing this manuscript. We are grateful to Professor D G Harnden for his comments. Dr Sarah Bundey acknowledges financial support from the National Fund for Research into Crippling Diseases at the outset of the study.

\section{References}

1 Knudson AG, Strong LC. Mutation and cancer: neuroblastoma and phaeochromocytoma. Am J Hum Genet $1972 ; 24: 514-32$.

2 Schappert-Kimmijser J, Hemmes GD, Nijland R. The heredity of retinoblastoma. Ophthalmologica 1960;151: 197-213.

3 Russell DS, Rubinstein LJ. Pathology of tumours of the nervous system. Chap 13, 4th ed. London: Arnold, 1977.

4 Dodge HJ, Benner MC. Neuroblastoma of adrenal medulla in siblings. Rocky Mt Med J 1945;42:35-8.

5 Zimmermann J. Ganglioneuroblastome als erbliche Systemerkrankung des Sympathicus. Beitr Pathol 1951; 111 :355-72.

6 Chatten J, Voorhess ML. Familial neuroblastoma. $N$ Engl J Med 1967;277:1230-6.

7 Gerson JM, Chatten J, Eisman S. Familial neuroblastoma: a follow up. $N$ Engl J Med $1974 ; 290: 1487$.

8 Griffin ME, Bolande RP. Familial neuroblastoma with regression and maturation to ganglioneurofibroma. Pediatrics $1969 ; 43: 377-82$.

- Feingold M, Gheradi GJ, Simons C. Familial neuroblastoma and trisomy 13. Am J Dis Child 1971;121:451.

10 Wong KY, Hanenson IB, Lampkin BC. Familial neuroblastoma. Am J Dis Child 1971;121:415-6.
11 Hardy PC, Nesbit ME. Familial neuroblastoma. Report of a kindred with a high incidence of infantile tumors. $J$ Pediatr 1972;80:74-7.

12 Wagget J, Aherne G, Aherne W. Familial neuroblastoma: report of two sib pairs. Arch Dis Child 1973;48:63-6.

13 Klein H, Plöchl E. Familiäres Neuroblastom der Nebennieren beim Neugeborenen. Munch Med Wochenschr 1974;116:1163-8.

14 Plöchl E. Genetische und biochemische Untersuchungen zum familiären Neuroblastom. Fortschr Med 1979;97: 1467-70.

15 Bergstrom JF, Long JM. Familial occurrence of ganglioneuromas. Tex Med 1974;70:62-5.

16 Pegelow CH, Ebbin AJ, Powars D, Towner JW. Familial neuroblastoma. J Pediatr 1975;87:763-5.

17 Arenson EB, Hutter JJ, Restuccia RD, Holton CP. Neuroblastoma in father and son. JAMA 1976;235:727-9.

18 Miller RW, Fraumeni JF, Hill JA. Neuroblastoma: epidemiologic approach to its origin. Am J Dis Child 1968; 115:253-61.

19 Stowens D. Neuroblastoma and related tumours. Arch Pathol 1957;63:451-9.

20 Mackay B, Luna MA, Butler JJ. Adult neuroblastoma. Cancer 1976;37:1334-51.

21 Bundey S, Harrison MJG, Marsden CD. A genetic study of torsion dystonia. J Med Genet 1975;12:12-9.

22 Wilson LMK, Draper GJ. Neuroblastoma, its natural history and prognosis: a study of 487 cases. $\mathrm{Br}$ Med J 1974 ;iii:301-7.

23 Li FP, Jaffe N. Progeny of childhood-cancer survivors. Lancet 1974 ;ii:707-9.

Requests for reprints to Dr S Bundey, Department of Clinical Genetics, Birmingham Maternity Hospital, Birmingham B15 2TG.

APPENDIX Summarised data on index patients and their families

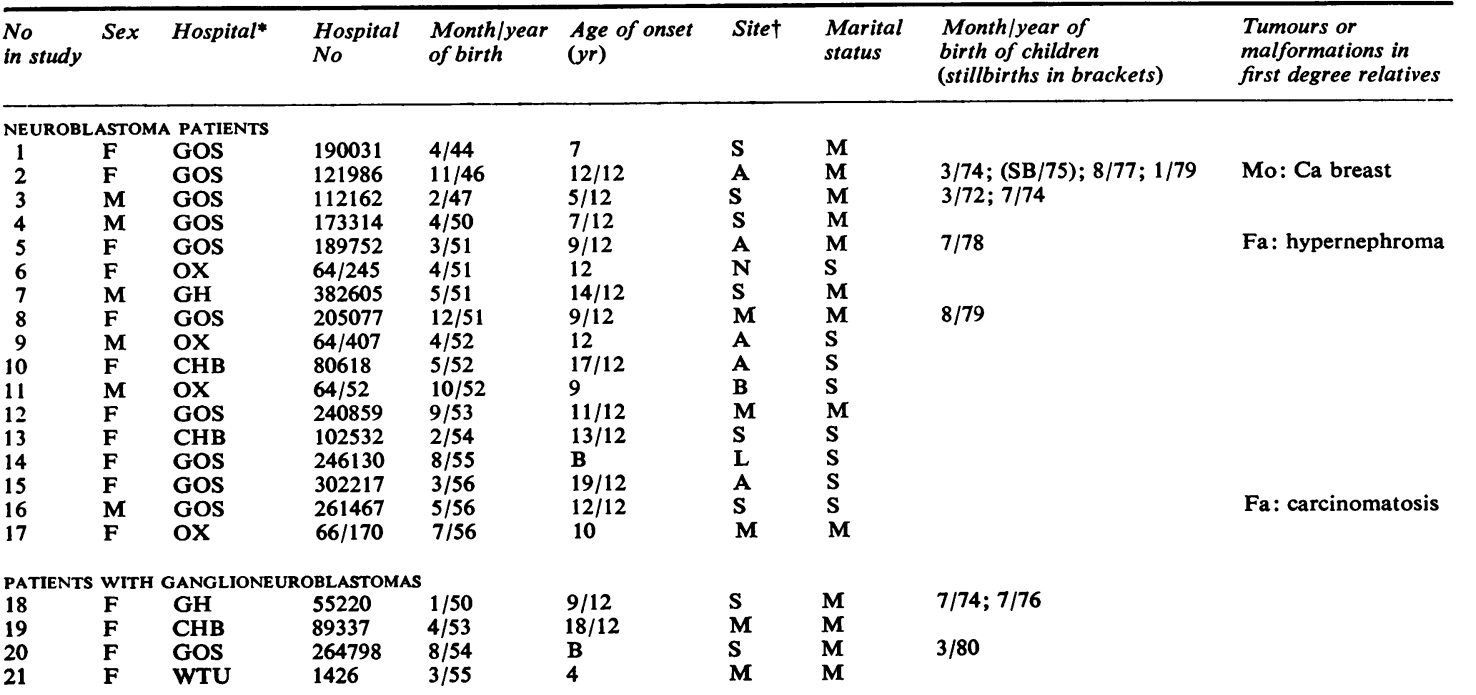


APPENDIX-continued

\begin{tabular}{|c|c|c|c|c|c|c|c|c|c|}
\hline $\begin{array}{l}\text { No } \\
\text { in study }\end{array}$ & $\operatorname{Sex}$ & Hospital* & $\begin{array}{l}\text { Hospital } \\
\text { No }\end{array}$ & $\begin{array}{l}\text { Month/year } \\
\text { of birth }\end{array}$ & $\begin{array}{l}\text { Age of onset } \\
(y r)\end{array}$ & Site $\dagger$ & $\begin{array}{l}\text { Marital } \\
\text { status }\end{array}$ & $\begin{array}{l}\text { Month/year of } \\
\text { birth of children } \\
\text { (stillbirths in brackets) }\end{array}$ & $\begin{array}{l}\text { Tumours or } \\
\text { malformations in } \\
\text { first degree relatives }\end{array}$ \\
\hline \multicolumn{10}{|c|}{ PATIENTS WITH GANGLIONEUROMAS } \\
\hline 22 & $\mathbf{M}$ & BH & A85518 & $3 / 02$ & 61 & $\mathbf{M}$ & $\mathbf{M}$ & $6 / 29 ; 12 / 31$ & \\
\hline 23 & $\mathbf{F}$ & GH & 110511 & $10 / 13$ & 59 & $\mathbf{A}$ & $\mathbf{M}$ & $8 / 39 ; 4 / 46$ & $\begin{array}{l}\text { Si: Ca spine } \\
\text { Si: Ca uterus }\end{array}$ \\
\hline 24 & $\mathbf{F}$ & $\mathrm{LC}$ & 55072 & $3 / 20$ & 39 & $\mathbf{M}$ & $\mathbf{M}$ & $145 ; / 49$ & \\
\hline 26 & $\mathbf{M}$ & WTU & 4419 & $10 / 23$ & 40 & $\mathbf{M}$ & $\mathbf{M}$ & $2 / 64 ; 2 / 66$ & \\
\hline 27 & $\mathbf{F}$ & QE & 842225 & $10 / 30$ & 42 & $\mathbf{A}$ & $\mathbf{M}$ & $152 ; 155$ & \\
\hline 28 & $\mathbf{F}$ & WTU & 1712 & $1 / 32$ & 27 & $\mathbf{M}$ & $\mathbf{M}$ & $3 / 54 ; 9 / 57$ & \\
\hline 29 & $\mathbf{F}$ & $\mathbf{W}$ & 64719 & $8 / 37$ & 14 & $\mathbf{M}$ & $\mathbf{M}$ & $4 / 63 ; 8 / 69$ & \\
\hline 30 & $\mathbf{F}$ & LC & 45997 & $2 / 41$ & 15 & $\mathbf{M}$ & $\mathbf{M}$ & $4 / 63 ; 3 / 65 ; 8 / 69$ & \\
\hline 31 & $\mathbf{M}$ & BH & A71665 & 142 & 18 & $\mathbf{M}$ & $\mathbf{M}$ & $9 / 77$ & Fa: plasmacytoma \\
\hline 32 & $\mathbf{F}$ & StB & 370634 & $4 / 43$ & 15 & $\mathbf{M}$ & $\mathbf{M}$ & $7 / 62 ; 2 / 65$ & \\
\hline 33 & $\mathbf{F}$ & StB & 295126 & $11 / 44$ & 7 & $\mathbf{M}$ & $\mathbf{M}$ & $9 / 76$ & \\
\hline 34 & $\mathbf{F}$ & GOS & 201544 & $9 / 45$ & 7 & $\mathbf{S}$ & $\mathbf{M}$ & & \\
\hline 37 & $\mathbf{F}$ & StB & 431933 & $5 / 47$ & 17 & $\mathbf{M}$ & $\mathbf{M}$ & $1 / 70 ; 5 / 71 ; 1 / 78$ & Da: pyloric stenosis \\
\hline 38 & $\mathbf{M}$ & W & 104530 & $2 / 48$ & 16 & $\mathbf{M}$ & $\mathbf{S}$ & & \\
\hline 39 & $\mathbf{F}$ & GOS & 227348 & $9 / 48$ & 6 & $\mathbf{S}$ & $\mathbf{M}$ & & \\
\hline 40 & $\mathbf{F}$ & BH & A26178 & $4 / 49$ & 4 & $\mathbf{M}$ & $\mathbf{M}$ & $10 / 74 ;(\mathrm{SB} / 76) ; 4 / 77$ & \\
\hline 41 & $\mathbf{F}$ & GOS & 261193 & $9 / 49$ & 14 & B & $\mathbf{M}$ & $3 / 73$ & \\
\hline 42 & $\mathbf{M}$ & LC & 55176 & $7 / 50$ & 9 & $\mathbf{M}$ & $\mathbf{S}$ & & \\
\hline 43 & $\mathbf{F}$ & LC & 44137 & $2 / 52$ & 3 & $\mathbf{M}$ & $\mathbf{M}$ & $8 / 78$ & $\begin{array}{l}\text { Mo: } \mathrm{Ca} \text { breast } \\
\mathrm{Fa}: \mathrm{Ca} \text { testis }\end{array}$ \\
\hline 44 & $\mathbf{M}$ & GOS & 240296 & $12 / 52$ & $6 / 12$ & $\mathbf{S}$ & $\mathbf{M}$ & & \\
\hline 45 & $\mathbf{F}$ & StB & 346284 & $3 / 54$ & B & $\mathbf{S}$ & $\mathbf{S}$ & & \\
\hline 46 & $\mathbf{F}$ & WTU & 2302 & $9 / 54$ & 4 & $\mathbf{M}$ & $\mathbf{M}$ & $7 / 74 ;(\mathrm{SB} / 75) ; 9 / 76 ; 10 / 79$ & SB: spina bifida \\
\hline 47 & $\mathbf{F}$ & GH & 111762 & $9 / 54$ & 18 & $\mathbf{M}$ & $\mathbf{M}$ & $8 / 75 ; 10 / 77$ & \\
\hline
\end{tabular}

* GOS, Hospital for Sick Children, London StB, St Bartholomew's Hospital, London

†A, adrenal gland

$\mathbf{S}$, sympathetic chain in abdomen or pelvis

BH, Brompton Hospital, London

LC, The London Chest Hospital

WTU, Walsgrave Hospital, Coventry (Thoracic Unit)

$\mathbf{M}$, sympathetic chain in posterior mediastinum

W, Warwick Hospital

$\mathrm{N}$, nose

L, liver deposits only

QE, Queen Elizabeth Hospital, Birmingham

B, bony deposits only

CHB, Children's Hospital, Birmingham

OX, Oxford Survey of Childhood Cancers

GH, General Hospital, Birmingham 